\title{
Diabetic Retinopathy Screening Methods and Programmes Adopted in Different Parts of the World - Further Insights
}

\author{
Janusz Pieczynski1,2 and Andrzej Grzybowski1,3 \\ 1. Chair of Ophthalmology, University of Warmia and Mazury, Olsztyn, Warszawska, Poland; \\ 2. The Voivodal Specialistic Hospital, Olsztyn, Zolnierska, Poland; 3. Department of Ophthalmology, Poznan City Hospital, Poznan, Poland
}

DOI: http://doi.org/10.17925/EOR.2015.09.02.161

\begin{abstract}
This editorial provides supplementary information to our recently published article titled 'Review of Diabetic Retinopathy Screening Method Programmes Adopted in Different Parts of the World' in European Ophthalmic Review, 2015;9(1):49-55.

\section{Keywords}

Diabetic retinopathy screening programmes, Portugal, US, Denmark

Disclosure: Janusz Pieczynski and Andrzej Grzybowski have no conflicts of interest to declare. No funding was received in the publication of this article. Open Access: This article is published under the Creative Commons Attribution Noncommercial License, which permits any non-commercial use, distribution, adaptation and reproduction provided the original author(s) and source are given appropriate credit.

Acknowledgement: The authors thank Professor David R Owens and Dr Rebecca L Thomas from Diabetes Research Group, Swansea University, Swansea, Wales, UK; Professor Jose Cunha-Vaz from AIBILI, CORC (Association for Innovation and Biomedial Research on Light and Image, Coimbra Ophthalmology Reading Center), Coimbra, Portugal; and Professor Toke Bek from Department of Ophthalmology, Aarhus University Hospital, Aarhus C, Denmark, for notifying about the other diabetic retinopathy programmes and their help in access to published and unpublished materials.

Received: 12 October 2015 Published Online: 21 December 2015 Citation: European Ophthalmic Review, 2015;9(2):Epub ahead of print

Correspondence: Janusz Pieczynski, Voivodal Specialistic Hospital, Zolnierska 18, 10-560 Olsztyn, Poland. E: janusz.pieczynski@op.pl
\end{abstract}

We recently published a review of diabetic retinopathy (DR) screening methods and programmes adopted in different parts of the world. ${ }^{1}$ After publication we learnt about more DR screening programmes and believed that this important information should be supplemented with data from Portugal, Denmark and the US (see Table 1).

\section{Portugal}

Ribeiro et al. ${ }^{2}$ presented a study on DR screening based on non-mydriatic fundus images augmented by automated disease/no disease grading. The screening programme has been performed in the Central Region of Portugal since 2001. They improved their screening by implementation of automated grading software, Retmarker screening technology, in 2011. They use mobile fundus cameras and a photographer/screener for each geographic area. The photographer/screener prepares weekly reports and sets of JPEG retina images and sends them to the grading centre. The automated, two-step grading analysis of retina pictures reduces the burden of reading centres and improves the sensitivity and specificity of DR detection. ${ }^{3}$ The grading process consists of two steps: (1) automated analysis and (2) human grading. Humans grade only pictures classified as suspected of having DR and pictures with poor quality. This procedure reduces the amount of fundus pictures required to be seen by humans.

\section{Denmark}

There is a national DR screening programme in Denmark, but there are no generalised English-language publications on it. All data are available on its Danish website. ${ }^{4}$ We can find some information about the programme from selected regional studies. Mehlsen et al. ${ }^{5}$ described a study based on the database for DR at the Department of Ophthalmology, Aarhus University Hospital. Their DR screening is based on fundus pictures, which are graded by a certified nurse grader and in problematic cases of retina by specialists. The same authors ${ }^{6}$ suggest that it is possible to customise DR screening intervals by construction of a model optimising DR intervals for low-risk DR patients. Knudsen et al. described another regional Danish DR screening study. They presented the North Jutland DR study based on digital-colour retina pictures and subsequent remote grading.

\section{The US}

Sanchez et al. ${ }^{8}$ described a telemedicine system of Joslin Vision Network developed in the Beetham Eye Institute, Boston, Massachusetts. It is based on digital five fields of non-simultaneous stereoscopic fundus photographs taken by non-mydriatic retinal cameras, and the photographs are digitally sent to the grading centre. The status of eye fundus and recommendations are sent to the patients. This system has been adopted in several US vision centres.

The new retinal imaging with ultrawide fundus pictures compared with non-mydriatic fundus imaging seems to be more efficient in DR detection. ${ }^{9}$ Silva et al. $^{10}$ suggest that ultrawide field retinal imaging graded by trained non-physicians has a good sensitivity and specificity for detection of DR. They concluded that immediate evaluation of pictures reduces grading-centre burden by $60 \%$ and patients' feedback should be expedited.

\section{Rectification}

We would like to correct the data in Table 1 in our recently published article titled 'Review of Diabetic Retinopathy Screening Methods and Programmes Adopted in Different Parts of the World'. ${ }^{\text {The data for }}$ Diabetic Retinopathy Screening Service for Wales in the column 'Instant Grading/Telemedicine' should be 'Telemedicine'. 


\section{Table 1: Supplement - Diabetic Retinopathy Screening Studies - Europe/Outside of Europe}

\begin{tabular}{|c|c|c|c|c|c|c|}
\hline Authors & Country & Study Type & Screening Method & IG/Telemedicine & Covered Population & Population - Local/Nationwide \\
\hline $\begin{array}{l}\text { Ribeiro } \\
\text { et al., } 2014\end{array}$ & Portugal & $\begin{array}{l}\text { Regional } \\
\text { programme }\end{array}$ & $\begin{array}{l}\text { Digital fundus non-mydriatic } \\
\text { cameras/two-field } 45^{\circ} \text { colour } \\
\text { fundus photos/mobile camera/ } \\
\text { two-step grading: first automated } \\
\text { and second human reading }\end{array}$ & $\begin{array}{l}\text { JPEG retina images weekly } \\
\text { sent to grading centre }\end{array}$ & $\begin{array}{l}\text { DMT1 and DMT2 } \\
\text { patients }\end{array}$ & Local \\
\hline $\begin{array}{l}\text { Mehlsen } \\
\text { et al., } 2011\end{array}$ & Denmark & Regional data & $\begin{array}{l}\text { Two-field } 60^{\circ} \text { fundus } \\
\text { photography; pupil dilatation }\end{array}$ & $\begin{array}{l}\text { Retina pictures graded } \\
\text { locally }\end{array}$ & DMT1 and DMT2 & $\begin{array}{l}\text { Local data (a part of } \\
\text { generalised programme) }\end{array}$ \\
\hline $\begin{array}{l}\text { Knudsen } \\
\text { et al., } 2006\end{array}$ & Denmark & $\begin{array}{l}\text { Regional } \\
\text { study }\end{array}$ & $\begin{array}{l}\text { Two-field } 50^{\circ} \text { digital fundus } \\
\text { photography; pupil dilatation }\end{array}$ & Telemedicine & DMT1 and DMT2 & Local study \\
\hline $\begin{array}{l}\text { Sanchez } \\
\text { et al., } 2010\end{array}$ & US & $\begin{array}{l}\text { Regional } \\
\text { programme }\end{array}$ & $\begin{array}{l}\text { Five fields of non-simultaneous } \\
\text { stereoscopic pairs of retina } \\
\text { pictures, sent electronically to } \\
\text { the grading centres }\end{array}$ & Telemedicine & $\begin{array}{l}\text { Patients of Joslin } \\
\text { Diabetes Center }\end{array}$ & Local programme \\
\hline
\end{tabular}

DMT1 = type 1 diabetes mellitus; DMT2 = type 2 diabetes mellitus; IG = instant grading

1. Pieczynski J, Grzybowski A, Review of diabetic retinopathy screening methods and programmes adopted in different parts of the world, European Ophthalmic Rev, 2015;9:49-55.

2. Ribeiro L, Oliveira CM, Neves C, et al., Screening for diabetic retinopathy in the central region of Portugal. Added value of automated 'disease/no disease' grading, Ophthalmologica, 2014 [Epub ahead of print].

3. Oliveira CM, Cristóvão LM, Ribeiro ML, Abreu JR, Improved automated screening of diabetic retinopathy, Ophthalmologica, 2011;226:191-7.

4. Available at: http///www.kcks-vest.dk/kliniske- kvalitetsdatabaser/diabase/ (accessed 25 November 2015. Mehlsen J, Erlandsen M, Poulsen PL, Bek T, Identification of independent risk factors for the development of diabetic retinopathy requiring treatment, Acta Ophthalmol, 2011;89:515-21.

6. Mehlsen J, Erlandsen M, Poulsen PL, Bek T, Individualized optimization of the screening interval for diabetic retinopathy: a new model, Acta Ophthalmol, 2012;90:109-14.

7. Knudsen LL, Lervang HH, Lundbye-Christensen S, GorstRasmussen A, The North Jutland County Diabetic Retinopathy Study: population characteristics, $\mathrm{Br} \perp$ Ophthalmol,
2006:90:1404-9

8. Sanchez CR, Silva PS, Cavallerano JD, et al., Ocular telemedicine for retinopathy and the Joslin Vision Network Semin Ophthalmol, 2010;25:218-24.

9. Silva PS, Cavallerano JD, Tolls D, et al., Potential efficiency benefits of nonmydriatic ultrawide field retinal imaging in an ocular telehealth diabetic retinopathy program, Diabetes Care, 2014;37:50-5.

10. Silva PS, Cavallerano JD, Tolson AM, et al., Real-time ultrawide field image evaluation of retinopathy in a diabetes telemedicine program, Diabetes Care, 2015:38:1643-9. 